\title{
THE PORTO PRIMAVERA DAM AND THE FLUVIAL TRANSPORT ON THE PORTO SÃO JOSÉ SECTION, PARANA RIVER
}

\author{
barragem de Porto Primavera e o transporte fluvial na seção de Porto São José, Rio Paraná
}

\author{
Edvard Elias Souza Filho *
}

\begin{abstract}
Resumo
A barragem de Porto Primavera provocou a diminuição da concentração da carga suspensa e a redução do porte das formas de leito do rio Paraná, mas os efeitos de sua construção sobre o transporte fluvial ainda não foram quantificados. Por esta razão, este trabalho tem como objetivo avaliar a influência da barragem sobre o transporte de sedimentos na seção de Porto São José. Para isso foram analisados os dados da série histórica da estação fluviométrica de Porto São José e as informações existentes na literatura. Foi utilizada análise de regressão para que a correlação entre a descarga fluvial e o transporte de sedimentos pudesse ser definida e as equações obtidas foram utilizadas para estimar o transporte em diferentes períodos de tempo. O transporte em suspensão antes da construção era de $214,1 \mathrm{~kg} / \mathrm{s}$, passou a ser de $222,2 \mathrm{~kg} / \mathrm{s}$ durante a obra e diminuiu para $56,4 \mathrm{~kg} / \mathrm{s}$ depois da barragem. O transporte de fundo era de $99,7 \mathrm{~kg} / \mathrm{s}$ durante a construção, diminuiu para $86,2 \mathrm{~kg} / \mathrm{s}$ em 1999 e 2000 e para 41,2 kg/s após 2001 . O transporte total diminuiu de 321,9 para 177,8 e finalmente para $91,2 \mathrm{~kg} / \mathrm{s}$ no mesmo período. Tais resultados permitiram concluir que a barragem reduziu o transporte em suspensão em $74,6 \%$, o transporte de fundo em $58,7 \%$, o transporte total em $71,7 \%$ e aumentou a proporção da carga de fundo de $33,9 \%$ para $44,5 \%$ do total.
\end{abstract}

Palavras-chave: Transporte sedimentar; Impacto de barragem; UHE Porto Primavera; Rio Paraná.

\begin{abstract}
The Porto Primavera Dam caused the decrease of the concentration of suspended load and reduction of the size of the bed forms of Paraná River, but the effects of the construction on fluvial transport have not yet been quantified. In order to do that, this paper aims to evaluate the influence of the dam on the sediment transport in the section of Porto São José. Thus, data of Porto São José Fluviometric Station, field and orbital images information available in literature were used. The data were analyzed by linear regression to obtain significant correlation between sediment transport and river discharge. The equations with significant coefficient of determination were used to estimate the annual average transport for different time periods. The suspended transport before construction was $214.1 \mathrm{~kg} / \mathrm{s}$, increased to $222.2 \mathrm{~kg} / \mathrm{s}$ during construction and decreased to $56.4 \mathrm{~kg} / \mathrm{s}$ after completion of the dam. The bed load transport was $99.7 \mathrm{~kg} / \mathrm{s}$ during the construction, decreased to $86.2 \mathrm{~kg} / \mathrm{s}$ during 1999 and 2000 and to $41.2 \mathrm{~kg} / \mathrm{s}$ after 2001. In the same period the total transport decreased from $321.9 \mathrm{~kg} / \mathrm{s}$ to 177.8 and finally to $91.2 \mathrm{~kg} / \mathrm{s}$. These results indicated that the Porto Primavera Dam reduced $74.6 \%$ of the suspended transport, $58.7 \%$ of the bed load transport, $71.7 \%$ of the total transport and increased the proportion of the bed load of $33,9 \%$ to $44.5 \%$ of total.
\end{abstract}

Key words: Sediment transport; Impact of dam; UHE Porto Primavera; Parana River.

\begin{abstract}
Résumé
Le barrage Porto Primavera a causé la diminution de la concentration de charge suspendue et la réduction de la taille des formes du fond de la rivière Paraná, mais les effets de la construction sur le transport fluvial n'ont toujours pas été quantifiés. Pour cette raison, ce document vise à évaluer l'influence du barrage sur le transport de sédiments dans la section de Porto São José. Ainsi, les données la série temporelle de la station de jaugeage de Porto São José et les informations existantes dans la littérature ont été utilisés. L'analyse de régression a été utilisée pour s'assurer que la corrélation entre le débit de la rivière et le transport des sédiments pourraient être définis et les équations obtenues ont été utilisées pour estimer le transport au cours des différentes périodes de temps. Le transport en suspension avant la construction était de $214,1 \mathrm{~kg} / \mathrm{s}$, en est venu à être $222,2 \mathrm{~kg} / \mathrm{s}$ pendant les travaux et a diminué à $56,4 \mathrm{~kg} / \mathrm{s}$ après le barrage. Le transport par charriage a été de $99,7 \mathrm{~kg} / \mathrm{s}$ au cours de la construction, a diminué à 86,2 kg/s au cours de l'année 1999 et 2000 et de $41,2 \mathrm{~kg} / \mathrm{s}$ après 2001 . Dans la même période, le transport solide total a diminué, passant de 321,9 $\mathrm{kg} / \mathrm{s}$ à 177,8 et enfin à $91,2 \mathrm{~kg} / \mathrm{s}$. Ces résultats ont montré que le barrage a réduit le transport en suspension dans $74,6 \%$, le transport par charriage dans $58,7 \%$, le transport solide total de $71,7 \%$ et a augmenté la proportion de la charge de fond de $33,9 \%$ pour $44,5 \%$ du total.
\end{abstract}

Mots-clés: Transport des sédiments; Impact de barrage; UHE Porto Primavera; Fleuve Paraná.

(*) Lecturer, Doctor of the State University of Maringá (Universidade Estadual de Maringá) - Avenida Colombo, 5790, CEP 87020-900, Maringá (PR), Brasil. Tel: (+55 44) 3031-4290 - eesfilho@uem.br 


\section{INTRODUCTION}

The formation of the reservoir of a dam modifies fluvial transport in the segment located downstream because it transforms a particular lotic segment into a lentic body of water. The reduced speed of the flow causes the sedimentation of the bedload in the vicinity of the backwater. The suspended load can settle partly or completely and the dissolved load itself can be altered according to the new physical / chemical conditions of the artificial lake.

The degree of interference depends on several variables, notably the size of the reservoir, the mode of operation, the residency time of the water, the type and location of the spillways and inlets and the physical-chemical characteristics of the water. This issue is not new in the literature and several authors have addressed it, such as Petts $(1979,1984)$, Grimshaw \& Lewin (1980), Williams \& Wolman (1984), Chien (1985), Petts \& Gurnall (2005), among many others.

The Porto Primavera Dam (UHE Eng. Sergio Motta) began to interfere with the Paraná River channel in late 1991, when cofferdams were used to construct the concrete structures (first phase of deviation). Between 1992 and 1994, the river only flowed in half the channel and from 1995 it started to flow in the newly constructed spillways as the free half of the channel had been isolated for the construction of the dam's remaining structures.

Construction ended in 1998 and the reservoir began to form in November of that year. The following year, Souza Filho (1999) predicted the reduction of the suspended load and the retention of the bedload. The decrease in the concentration of suspended sediment and the transport had already been verified during construction of the dam by samples taken between 1993 and 1995 (STEVAUX \& TAKEDA, 2002) and was confirmed by Crispin (2001). The cut in the bedload supply was verified by field surveys conducted in 2000 near the dam (ROCK \& SOUZA FILHO, 2008) and ratified by Martins \& Stevaux (2006) and Martins et al. (2009). The dissolved load was also modified and the river lost phosphorus, iron, silicon, magnesium, calcium, strontium, manganese, zinc, cadmium, lead, aluminum, barium, cobalt and copper but there was an increase in potassium, sodium, chrome and nickel (SOUZA FILHO et al. 2010).

The information available in these articles indicates that fluvial transport decreased from the beginning of the construction of the dam, but the magnitude of this reduction has not been assessed yet. That is, all the evidence points to a confirmation of this change, but the intensity with which it occurred is still unknown.

For this reason, the objective of this study is the evaluation of detrital transport in the Porto São José section of the Paraná River in the period prior to the dam, during its construction and in the period after construction, in order to ascertain the influence the UHE Porto Primavera had on this variable.

\section{STUDY AREA}

The Porto São José section is located in the middle part of the Upper Paraná River, just over $35 \mathrm{~km}$ downstream of the Porto Primavera Dam and nearly 12 kilometers below the mouth of the Paranapanema River (Figure 1).

This site serves as a reference section for the studies of the Paraná River, as in addition to being located in a single channel it has had an active fluviometric station since October 1963 (Station Porto São José, registration 64575000). It was the scene for gathering data on the concentration of suspended sediments by the National Water Agency (ANA), by ITAIPU BINACIONAL and various researchers. 


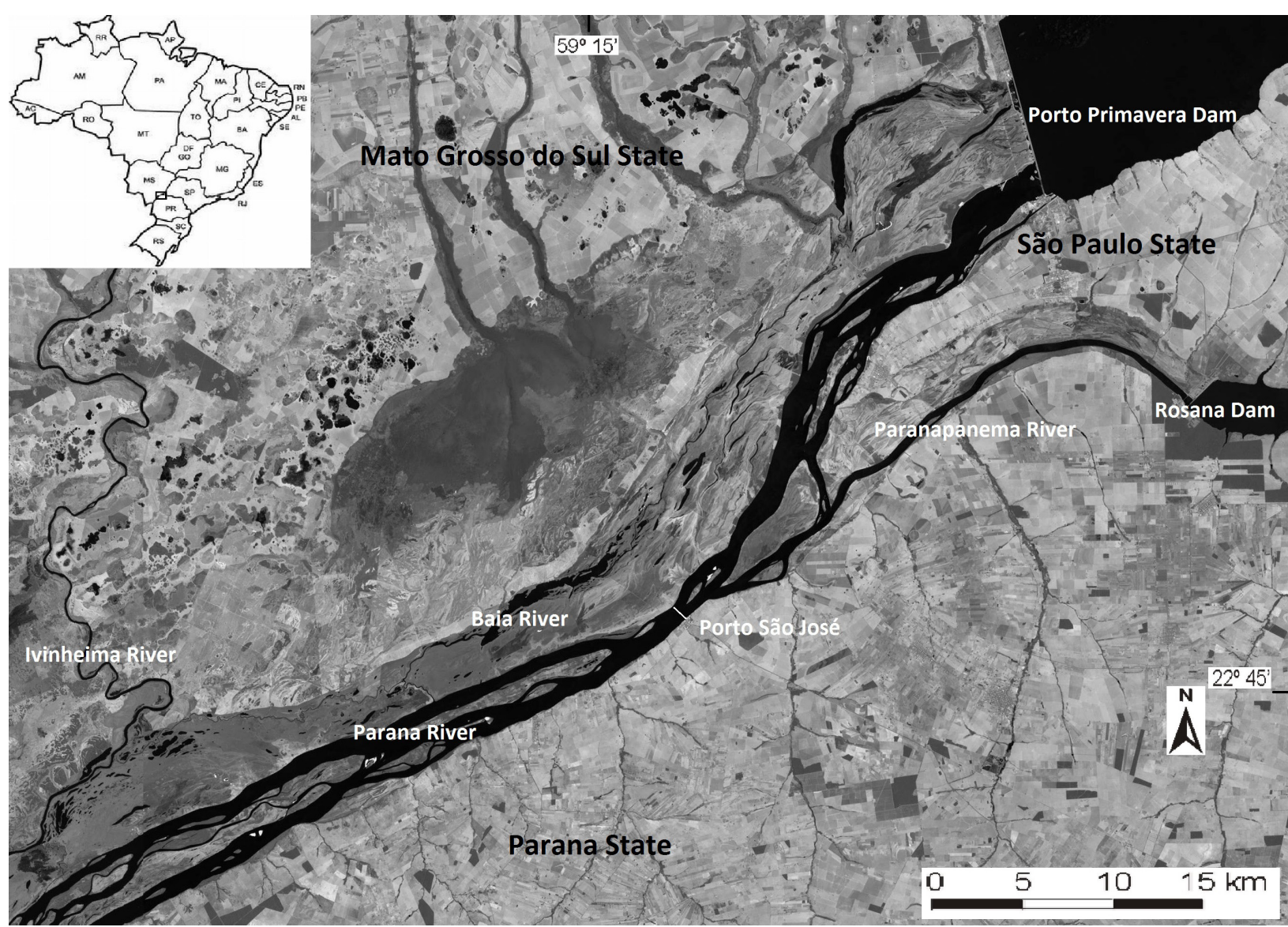

Figure 1 - Location of the Porto São José section (ETM image cropped, 223/076 of 11/18/1999).

The section is 1140 meters wide and is asymmetric because the thalweg is located near the left bank (Figure 2). The average flow rate recorded between 1964 and 2012 was $8822 \mathrm{~m} 3 / \mathrm{s}$ (average height of $3.35 \mathrm{~m})$, with a minimum value of $2551 \mathrm{~m} 3 / \mathrm{s}(0.27 \mathrm{~m})$ and a maximum of $33698 \mathrm{~m} 3 / \mathrm{s}$ $(8.74 \mathrm{~m})$.

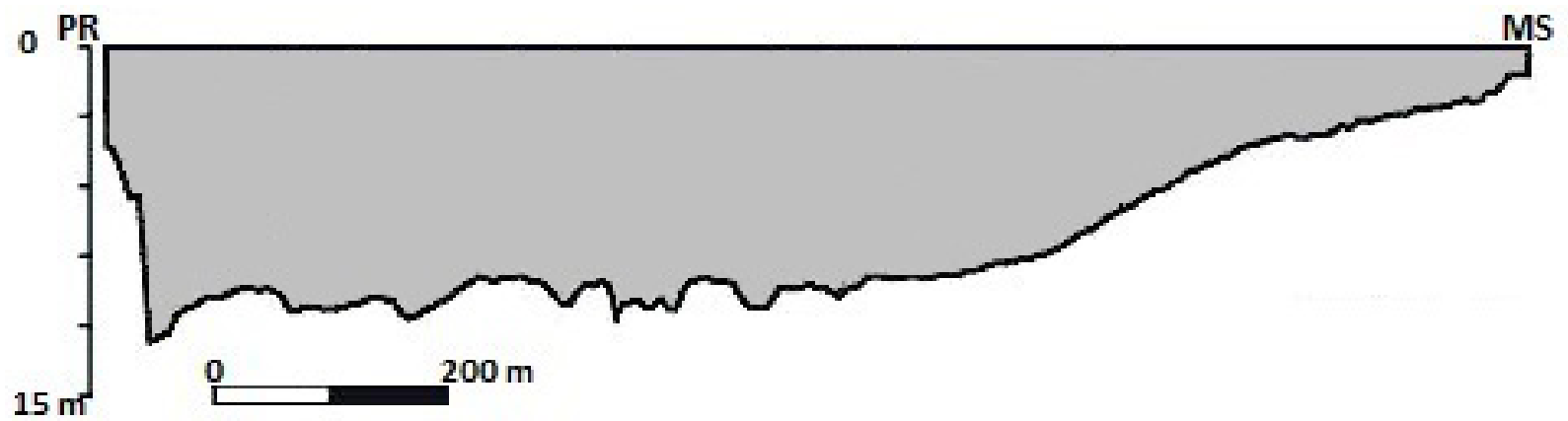

Figure 2 - Section of Porto São José (Modified from Martin \& Stevaux, 2005).

The transport of suspended sediment was evaluated by several authors (STEVAUX, 1994; STEVAUX \& TAKEDA, 2002; CRISPIM, 2001), but all these estimates were carried out for specific periods and the total information available is greater than those already evaluated. The oldest data were obtained by the DNAE in 1979 and by ITAIPU BINACIONAL in the period 1986-1988, by field sampling. In the latter case, the company calculated the average transport of $856 \mathrm{~kg} / \mathrm{s}$ for the three years sampled (ITAIPU BINACIONAL, 1990).

In the period between 1986 and 2001 the DNAE (and then ANA) carried out collections at the Porto São José Downstream station (registration 64575003). All the results are available on 
the HIDROWE website maintained by ANA. The section has also been monitored by researchers from the UEM, who conducted systematic surveys in the periods 1993-1995 and 2000-2001. The average values for the samples are shown in Table 1.

Table 1 - Number of collections and average values of concentration and suspended transport obtained by the various samples taken from the river section

\begin{tabular}{c|c|c|c|c|c} 
Period & $\mathbf{1 9 7 9}$ & $\mathbf{1 9 8 6 - 1 9 8 8}$ & $\mathbf{1 9 8 6 - 2 0 0 1}$ & $\mathbf{1 9 9 3 - 1 9 9 5}$ & $\mathbf{2 0 0 0 - 2 0 0 1}$ \\
\hline Source & ANA & Stevaux (1994) & ANA & Stevaux \& Takeda (2002) & Crispim (2001) \\
\hline Number & 13 & 14 & 44 & 26 & 13 \\
\hline Concentration $(\mathrm{mg} / \mathrm{l})$ & 65,2 & 24,9 & 11,4 & 14,8 & 10,8 \\
\hline Transport $(\mathrm{kg} / \mathrm{s})$ & 468 & 209,3 & 101,2 & 142,7 & 85,6
\end{tabular}

The data in Table 1 do not represent the average concentration in the periods, but only the average of the samples taken. The same can be said regarding the values for transport. However, they show that there was a clear reduction in the transport in suspension during the construction period and after the completion of the works, especially when the information for the period between 1986 and 2001 are separated into distinct time intervals (Table 2).

Table 2 - Average concentration and average suspended transport of samples collected in 1986-1991, 1992-1998 and 1999-2001

\begin{tabular}{c|c|c|c} 
Period & $\mathbf{1 9 8 6 - 1 9 9 1}$ & $\mathbf{1 9 9 2 - 1 9 9 8}$ & $\mathbf{1 9 9 9 - 2 0 0 1}$ \\
\hline Source & \multicolumn{3}{|c}{ ANA } \\
\hline Number & 19 & 15 & 10 \\
\hline Concentration $(\mathrm{mg} / \mathrm{l})$ & 17,4 & 9 & 3,6 \\
\hline Transport $(\mathrm{kg} / \mathrm{s})$ & 157,2 & 80 & 26,2
\end{tabular}

In addition to the field data, imaging also obtained information about the concentration of sediment in the Porto São José section, according to Montanher \& Souza Filho (2010, 2011 and 2015) and Águas et al. (2013). Table 3 shows the average values of sediment concentration obtained by the aforementioned authors and the average transport calculated from the concentration and flow data.

Table 3 - Average concentration and suspended transport obtained from satellite images

\begin{tabular}{c|c|c|c|c|c|c} 
Period & $1984-1991$ & $1992-1998$ & $1999-2011$ & $1984-1991$ & $1993-1997$ & $1999-2011$ \\
\hline Source & \multicolumn{2}{|c|}{ Montanher \& Souza Filho $(2010,2011,2015)$} & \multicolumn{3}{|c}{ Águas et al. $(2013)$} \\
\hline Number & 44 & 23 & 73 & 7 & 9 & 24 \\
\hline Concentration (mg/1) & 27 & 20,7 & 5,5 & 138,5 & 135 & 5,6 \\
\hline Transport (kg/s) & 258,7 & 209,8 & 51,8 & 1115,8 & 1119,7 & 43,4
\end{tabular}

The concentration values obtained by Águas et al. (2013) for the intervals between 1984 and 1991 and between 1993 and 1997 are much higher than those obtained by Montanher \& Souza Filho (2010, 2011 and 2015) and from field data (Tables 1 and 2), which provided very high values for sediment transport. On the other hand, the values obtained by the other two authors have similar orders of magnitude to those obtained in the field, although higher. In both cases, there is considerable reduction in the average value of both variables after the formation of the reservoir.

The transport of the bedload is still poorly understood, because there is very little information available. The first evaluation was carried out by ITAIPU BINACIONAL (1990), which reached the value of $95.1 \mathrm{~kg} / \mathrm{s}$ for the period between 1986 and 1989. However, this value was based on the transport in suspension data, it being considered that the bedload corresponds to two tenths of the solid suspension discharge. In a later report, the company came to consider that the bedload 
discharge corresponded to $32.3 \%$ of the suspended load, a valid ratio for the transport in the period before 1998 (ITAIPU BINACIONAL, 1996). Since direct measurements were not carried out, it is not possible to consider the results.

The only two field evaluations conducted in the Porto São José section available in the literature occurred in 2002 and 2003 (MARTINS \& STEVAUX, 2005) and between 2005 and 2007 (MARTINS et al., 2009). Overall six surveys were carried out, whose results are shown in Table 4.

Table 4 - Bedload transport in the Porto São José section, according to Martins \& Stevaux (2005) and Martins et al. (2009)

\begin{tabular}{c|c|c|c} 
Months & Year & Transport $(\mathbf{k g} / \mathbf{s})$ & Average discharge $\left(\mathbf{m}^{3} / \mathbf{s}\right)$ \\
\hline November December & 2002 & 34,03 & 6257 \\
\hline June July & 2003 & 31,36 & 6762 \\
\hline November December & 2003 & 32,55 & 7625 \\
\hline July & 2005 & 32,59 & 9769 \\
\hline May & 2006 & 37,71 & 7953 \\
\hline January February & 2007 & 115,23 & 18136
\end{tabular}

Since there is no data prior to that displayed in Table 4, it is not possible to assess the dam's effect on this variable. However, the variation in the size of the subaqueous dunes and their speed of displacement (Table 5) show that it is very likely that the bedload transport has also been modified.

The variation in the height of the dunes may be more important than the change in their speed of displacement because apparently the dam did not modify this last variable, since it depends on fluvial discharge, as shown by Souza Filho \& Rigon (2012). According to these authors the displacement speed of the dunes $(\mathrm{Vd})$ is a function of fluvial discharge, a relation expressed by $\mathrm{Vd}$ $=-29.3034+0.0108 . \mathrm{Q}$, with a coefficient of determination of 0.8842 and an error of $3.9 \mathrm{~m} / \mathrm{month}$.

Table 5 - The average height variation $(\mathrm{H})$ and the displacement speed of the subaqueous dunes (Vd) in the period between 1994 and 2007

\begin{tabular}{c|c|c|c|c}
\hline Period & $\mathbf{1 9 9 4 - 1 9 9 5}$ & $\mathbf{2 0 0 0 - 2 0 0 1}$ & $\mathbf{2 0 0 2 - 2 0 0 3}$ & $\mathbf{2 0 0 5 - 2 0 0 7}$ \\
\hline Source & Stevaux \& Takeda (2002) & Crispim (2001) & Martins \& Stevaux (2005) & Martins et al. (2009) \\
\hline $\mathbf{H ~ ( m )}$ & 2,21 & 2,20 & 1,15 & 1,23 \\
\hline Vd (m/day) & 2,23 & 2,06 & 1,61 & 3,15 \\
\hline
\end{tabular}

The transport of the dissolved load has never been evaluated because systematic surveys were not carried out for this variable. The concentration data of some elements were obtained in some surveys such as Rauber et al. (1992), Thomaz et al. (1992, 1994) Zanetti et al. (2009), but none evaluated the total dissolved load.

\section{METHODOLOGY}

This work was developed by collecting the information available in the literature and institutional databases. In the case of the literature review on transport in suspension, emphasis was given to approaches that had the following characteristics: a) systematic collections carried out for a significant period on the Porto São José section; b) they presented data on the sediment concentrations and the day of collection; c) they made clear what form of sampling was used to obtain the data.

This selection was necessary because the section under study is very large and the variability of the concentration of suspended sediment is very high. Therefore, it is prudent for the statistical analysis to be made using data, which can be compared with each other, either with regard to location, or with regard to the number of samples. Similarly, the requirement of the date and the concentration value is justified due to the way the data will be analyzed. On the other hand, the 
selection reduced the number of sources to the work of Crispin (2001), Montanher \& Souza Filho (2010, 2011 and 2015), Águas et al. (2013) and the historical series from stations in Porto São José and Porto São José Downstream.

The data analysis was initiated by the formation of four spreadsheets in Microsoft Excel, with the dates and sediment concentrations. A sheet was prepared for each of the data sets: Crispim (2001), Montanher \& Souza Filho (2010, 2011 and 2015), Águas et al. (2013) and the stations of Porto São José and Porto São José Downstream (ANA data).

The value of the fluvial discharge on the respective date was added to the initial data, with reference to the historic series of flow for the aforementioned stations. The transport on each day was calculated by multiplying the concentration value by the value of fluvial discharge. The transport values shown in the columns 1979 and 1986 to 2001 of Table 1 and Table 3 were obtained in this fashion.

However, the concentration of sediment and river discharge has a high temporal variability, which causes this characteristic in the transport in suspension. That is, the transport is a continuous and highly variable process. In this case, the most appropriate evaluation should be continuous, which unfortunately is not possible. Among the aforementioned variables, the only one that approaches this continuity is the discharge, since there are daily average values, although these values are inferred from the water level measurements.

Thus, a way to transform the data on concentration (and transport), which are discrete and few, into daily data (almost continuous) is to establish a correlation between concentration and discharge or between transport and flow. If the concentration of suspended sediment is dependent on the liquid discharge, the average daily value can be calculated from the data on average daily flow, which would allow the attainment of the value of average daily transport. If transport were dependent on the discharge, the daily average value would be a function of the average daily flow.

Therefore, the processing of the data sought to verify the existence of a correlation between the discharge and the other two variables. The equations that describe the relations between the variables were obtained by regression analysis using the STATISTICA "software".

Each of the sheets was analyzed separately because the data were obtained in different ways. In addition, the data were grouped into different time slots, because apparently the Porto Primavera dam modified the sediment transport. Statistical analysis was initially performed for the year 1979 and for the periods 1986-1992, 1993-1998 and 1999-2001 (data from ANA). Crispim's (2001) data covered the period 2000-2001, whereas Montanher \& Souza Filho's (2010, 2011 and 2015) data were divided into the intervals 1984-1992, 1993-1998 and 1999-2011. Data from Águas et al. (2013) were grouped in the periods 1984-1991, 1993-1997 and 1999-2011.

After the analyses were carried out, each period was subdivided again by the interval of one year in order to assess which set had best determination coefficient. The equations with a better correlation coefficient were used for the calculation of the transport for the respective period and the results were compared.

In the case of bedload transport, the authors used the volume of the bed forms and the displacement speed to assess the transport of bed sediments in the section of Porto São José (MARTINS \& STEVAUX, 2005 and MARTINS et al., 2009). However, the transport values obtained refer to the periods in which the surveys were conducted and do not allow the evaluation of the transport performed by the Paraná River in the period after the dam. To carry out such a calculation it is also necessary to establish a relationship between the bed transport and river discharge.

The relationship between the bed transport and fluvial discharge was established through regression analysis between the flow and transport, from the data obtained in each survey of the two aforementioned authors. However, the equation obtained cannot be applied prior to 1999 because the dunes were higher (Table 5), furthermore, they may not be applied to the years 2000 and 2001 because the size of the dunes was equivalent to in the construction period. 
As the data prior to the completion of the dam are limited to the height and displacement speed of subaqueous dunes, it is necessary to establish a relationship between these variables and the transport of bed sediments. Since the displacement speed is a function of the discharge (Souza Filho \& Rigon, 2012) and apparently, the height of the dunes remained stable between 1994 and 2001, these variables can be used to estimate the bed transport in the period of construction of the dam.

Unfortunately, the assessment of bed sediment transport in the period prior to the start of construction cannot be done because the only information about the height of the dunes is that they varied from 1.5 to $7.0 \mathrm{~m}$ (Stevaux, 1994). This information is not sufficient to perform a reliable calculation.

\section{RESULTS AND DISCUSSION}

\section{TRANSPORT IN SUSPENSION IN THE PERIOD PRIOR TO CONSTRUCTION OF THE PORTO PRIMAVERA DAM}

The analysis of the regression data for1979 (ANA) showed that there was a high ratio of dependence between the sediment concentration and transport in suspension, while the fluvial discharge had little influence on the variable, as shown by the values of the coefficient of determination shown in Table 6.

Table 6 - Coefficient of determination values (r2) of the linear regression between the variables: discharge, concentration and suspended transport, obtained in 1979

\begin{tabular}{c|c|c} 
& Concentration & Transport \\
\hline Fluvial Discharge & 0,2346 & 0,4259 \\
\hline Concentration & & 0,9529
\end{tabular}

The equation that describes the relationship between the discharge and transport in suspension (Ts) is Ts $=-676.8416+0.1627$.Q with a standard error of $164.29 \mathrm{~kg} / \mathrm{s}$. Since the average discharge (Q) in 1979 was $8300 \mathrm{~m} 3 / \mathrm{s}$, the average annual value of transport in 1979 would be $673.57 \pm$ $164.29 \mathrm{~kg} / \mathrm{s}$.

Data analysis of the period between 1986 and 1992 (ANA) again demonstrated a high ratio between concentration and transport ( $\mathrm{r} 2$ of 0.9601$)$ and a low relationship between the discharge and the concentration or the transport ( $\mathrm{r} 2$ of 0.2402 and 0.4575 , respectively). The resulting equation of the linear regression between discharge and transport is $\mathrm{Ts}=-399.3482+0.069$.Q with a standard error of $125.78 \mathrm{~kg} / \mathrm{s}$. The use of values for the annual average discharge for the period obtained the results shown in Table 7.

Table 7 - Average annual discharge (Q) and suspended transport (medium, minimum and maximum) in the Porto São José’s section José between 1986 and 1992 (ANA)

\begin{tabular}{c|c|c|c|c}
\multirow{2}{*}{ Year } & \multirow{2}{*}{$\mathbf{Q}\left(\mathbf{m}^{\mathbf{3}} / \mathbf{s}\right)$} & \multicolumn{3}{|c}{ Suspended transport $\mathbf{( k g / \mathbf { s } )}$} \\
\cline { 3 - 5 } & & Medium & Minimum & Maximum \\
\hline 1986 & 7723 & 133,54 & 7,76 & 259,32 \\
\hline 1987 & 8140 & 162,31 & 36,53 & 288,09 \\
\hline 1988 & 9023 & 223,24 & 97,46 & 349,02 \\
\hline 1989 & 9015 & 222,69 & 96,91 & 348,47 \\
\hline 1990 & 8695 & 200,61 & 74,83 & 326,39 \\
\hline 1991 & 9517 & 257,32 & 131,54 & 383,10 \\
\hline 1992 & 10273 & 309,49 & 183,71 & 435,27 \\
\hline Average & $\mathbf{8 9 1 2}$ & $\mathbf{2 1 5 , 6 0}$ & $\mathbf{8 9 , 8 2}$ & $\mathbf{3 4 1 , 3 8}$
\end{tabular}


Despite the margins of error, the transport in suspension in between 1986 and 1992 was less than that estimated for the year 1979 as the largest maximum value of the period (435.3 k/s in 1992) is below the minimum value for $1979(509.3 \mathrm{~kg} / \mathrm{s})$.

The regression analyzes involving part of the period had higher coefficients of determination for the biennium 1986-1987 (0.6078), for 1987 (0.6529) and for 1988 (0.5584), allowing the results to be refined, according to Table 8 .

Table 8 - Equations resulting from the linear regression analysis between the discharge and transport, the coefficient of determination ( $\mathrm{r} 2$ ), standard error and suspended transport (medium, minimum and maximum) in the biennium 1986-1987 and in 1987 and 1988 (ANA)

\begin{tabular}{c|c|c|c|c|c|c}
\multirow{2}{*}{ Year } & \multirow{2}{*}{ Equations } & \multirow{2}{*}{$\mathbf{r}^{2}$} & \multirow{2}{*}{ Standard error } & \multicolumn{3}{|c}{ Suspended transport $(\mathbf{k g} / \mathbf{s})$} \\
\cline { 5 - 7 } & & & & Medium & Minimum & Maximum \\
\hline 1986 & \multirow{2}{*}{$\mathrm{Ts}=-675,4201+0,1102 . \mathrm{Q}$} & 0,6078 & 87,00 & 175,66 & 88,66 & 262,66 \\
\cline { 1 - 4 } 1987 & & & 221,61 & 134,61 & 308,61 \\
\hline 1987 & $\mathrm{Ts}=-667,7707+0,1112 . \mathrm{Q}$ & 0,6529 & 68,98 & 237,40 & 168,02 & 306,38 \\
\hline 1988 & $\mathrm{Ts}=-344,3033+0,0631 . \mathrm{Q}$ & 0,5584 & 105,03 & 225,05 & 120,02 & 330,08
\end{tabular}

The data obtained by Montanher \& Souza Filho (2010, 2011 and 2015) for 1984-1992 showed a high coefficient of determination for the linear regression between the concentration and transport ( $\mathrm{r} 2$ of 0.8485 ) and low coefficients for the regressions performed with the discharge. The highest rate was obtained in the regression between the discharge and transport ( $\mathrm{r} 20.3840$ ), but it is too low for the equation obtained to be used reliably. However, the analyses carried out year by year had better coefficient of determination values for the years 1986-1992; the results are shown in Table 9.

Table 9 - Equations resulting from the linear regression analysis between discharge and transport, the coefficient of determination ( $\mathrm{r} 2$ ), standard error and annual suspended transport (medium, minimum and maximum) between 1986 and 1992 (MONTANHER \& SOUZA FILHO, 2010, 2011 and 2015)

\begin{tabular}{c|c|c|c|c|c|c}
\multirow{2}{*}{ Year } & \multirow{2}{*}{ Equations } & \multirow{2}{*}{$\mathbf{r}^{\mathbf{2}}$} & \multirow{2}{*}{ Standard error } & \multicolumn{3}{|c}{ Suspended Transport $(\mathbf{k g} / \mathbf{s})$} \\
\cline { 5 - 7 } & & & & Medium & Minimum & Maximum \\
\hline 1986 & $\mathrm{Ts}=-595,7401+0,0963 . \mathrm{Q}$ & 0,4652 & 79,28 & 147,99 & 68,70 & 227,26 \\
\hline 1987 & $\mathrm{Ts}=-1562,8005+0,2163 . \mathrm{Q}$ & 0,8816 & 64,17 & 197,88 & 133,71 & 262,05 \\
\hline 1988 & $\mathrm{Ts}=-444,8607+0,071 . \mathrm{Q}$ & 0,6383 & 90,15 & 195,77 & 105,62 & 285,92 \\
\hline 1989 & $\mathrm{Ts}=-666,2335+0,1042 . \mathrm{Q}$ & 0,8382 & 69,78 & 273,13 & 203,35 & 342,91 \\
\hline 1990 & $\mathrm{Ts}=-88,1954+0,0377 . \mathrm{Q}$ & 0,4873 & 91,81 & 239,61 & 147,80 & 331,42 \\
\hline 1991 & $\mathrm{Ts}=-108,8171+0,0461 . \mathrm{Q}$ & 0,4300 & 160,03 & 329,92 & 169,89 & 489,95 \\
\hline 1992 & $\mathrm{Ts}=-114,9438+0,0267 . \mathrm{Q}$ & 0,6518 & 69,46 & 159,35 & 89,89 & 228,81 \\
\hline Average & & & & $\mathbf{2 2 0 , 5 2}$ & $\mathbf{1 3 1 , 2 8}$ & $\mathbf{3 0 9 , 7 6}$
\end{tabular}

The analysis of the data by Águas et al. (2013) for the period 1984-1991 showed that the concentration has a strong influence on the transport ( $\mathrm{r} 2$ of 0.9967 ) and the discharge does not influence the concentration of sediment or the transport ( $\mathrm{r} 2$ less than 0.01 ). The analysis of annual data cannot be performed because the number of samples in each year is very low.

Field data obtained by ANA and the data obtained by satellite images (MONTANHER \& SOUZA FILHO, 2010, 2011 and 2015) resulted in similar values for the transport of suspended load, although when considering the coefficient of determination, the transport estimated by image was more reliable.

\section{TRANSPORT IN SUSPENSION DURING THE CONSTRUCTION OF THE PORTO PRIMAVERA DAM}

The analysis of data obtained by ANA for the 1993-1998 period had a lower coefficient of determination than the previous ones for the regression between concentration and transport ( $\mathrm{r} 2$ of 0.7797 ), while the regression between the discharge and transport did not have a significant 
relationship ( $\mathrm{r} 2$ of 0.3190). However, the values of the coefficient of determination between the discharge and transport in the period 1993-1994 and 1998 were significant and allowed for the use of the respective equations to evaluate the transport averages of these three years (Table 10).

Table 10 - The average annual discharge (Q), resulting equations of the linear regression analysis between the discharge and the suspended transport, the coefficient of determination ( $\mathrm{r} 2)$, standard error and annual suspended transport (medium, minimum and maximum) in 1993, 1994 and 1998 (ANA)

\begin{tabular}{c|c|c|c|c|c|c|c}
\multirow{2}{*}{ Year } & \multirow{2}{*}{$\mathbf{Q}\left(\mathbf{m}^{3} / \mathbf{s}\right)$} & Equations & \multirow{2}{*}{$\mathbf{r}^{2}$} & \multirow{2}{*}{ Standard error } & \multicolumn{3}{|c}{ Suspended transport $(\mathbf{k g} / \mathbf{s})$} \\
\cline { 6 - 8 } & & & & & Medium & Minimum & Maximum \\
\hline 1993 & 9523 & \multirow{2}{*}{$\mathrm{Ts}=210,8723-0,0187 . \mathrm{Q}$} & 0,7871 & 7,58 & 32,792 & 25,212 & 40,372 \\
\hline 1994 & 8708 & & & & 48,033 & 40,453 & 55,613 \\
\hline 1998 & 9450 & $\mathrm{Ts}=-139,1284+0,0225 . \mathrm{Q}$ & 0,7525 & 24,63 & 73,497 & 48,867 & 98,127 \\
\hline Average & & & & & $\mathbf{5 1 , 4 4}$ & $\mathbf{3 8 , 1 8}$ & $\mathbf{6 4 , 7 0}$
\end{tabular}

Montanher \& Souza Filho's data (2010, 2011 and 2015) covering the construction period of the dam showed significant results for the regression analysis between discharge and transport ( $\mathrm{r} 2$ of 0.7039 ) and the resulting equation ( $\mathrm{Ts}=-221.1345+0.0471 . \mathrm{Q})$ showed an error of $71.88 \mathrm{k} / \mathrm{s}$. The resulting values are shown in Table 11.

Table 11 - Average annual discharge (Q) and annual suspended transport (medium, minimum and maximum) in the section and Porto São José between 1993 and 1998 (MONTANHER \& SOUZA FILHO, 2010, 2011 and 2015)

\begin{tabular}{c|c|c|c|c}
\multirow{2}{*}{ Year } & \multirow{2}{*}{$\mathbf{Q}\left(\mathbf{m}^{3} / \mathbf{s}\right)$} & \multicolumn{3}{|c}{ Suspended transport $\mathbf{( k g / s )}$} \\
\cline { 3 - 5 } & & Medium & Minimum & Maximum \\
\hline 1993 & 9523 & 227,40 & 155,52 & 299,28 \\
\hline 1994 & 8708 & 189,01 & 117,13 & 260,89 \\
\hline 1995 & 9175 & 211,01 & 139,13 & 282,89 \\
\hline 1996 & 8112 & 160,94 & 89,06 & 232,82 \\
\hline 1997 & 9980 & 248,92 & 177,04 & 320,80 \\
\hline 1998 & 9450 & 223,96 & 152,08 & 295,84 \\
\hline Average & $\mathbf{9 1 5 8}$ & $\mathbf{2 1 0 , 2 1}$ & $\mathbf{1 3 8 , 3 3}$ & $\mathbf{2 8 2 , 0 9}$
\end{tabular}

The analysis of annual data obtained higher coefficient of determination values for the years 1993 to 1995 and for 1997, which permitted a more reliable estimate of the average transport for these years (Table 12).

Table 12 - Equations resulting from the linear regression analysis between the discharge and suspended transport, the coefficient of determination (r2), the standard error and annual suspended transport (medium, minimum and maximum) for the period between 1993 and 1995 and for 1997

(MONTANHER \& SOUZA FILHO, 2010, 2011 and 2015)

\begin{tabular}{c|c|c|c|c|c|c}
\multirow{2}{*}{ Year } & \multirow{2}{*}{ Equations } & \multirow{2}{*}{$\mathbf{r}^{2}$} & \multirow{2}{*}{ Standard error } & \multicolumn{3}{|c}{ Suspended transport (kg/s) } \\
\cline { 5 - 7 } & & & & Medium & Minimum & Maximum \\
\hline 1993 & $\mathrm{Ts}=12,425+0,0309 . \mathrm{Q}$ & 0,9073 & 56,83 & 306,69 & 249,86 & 363,52 \\
\hline 1994 & $\mathrm{Ts}=-212,6656+0,0459 . \mathrm{Q}$ & 0,7576 & 78,86 & 187,03 & 108,17 & 265,89 \\
\hline 1995 & $\mathrm{Ts}=-235,5431+0,0385 . \mathrm{Q}$ & 0,8368 & 12,46 & 117,69 & 105,23 & 130,15 \\
\hline 1997 & $\mathrm{Ts}=-889,6977+0,1229 . \mathrm{Q}$ & 0,7534 & 70,67 & 336,84 & 266,17 & 407,51 \\
\hline Average & & & & $\mathbf{2 3 7 , 0 6}$ & $\mathbf{1 8 2 , 3 6}$ & $\mathbf{2 9 1 , 7 7}$
\end{tabular}

The data of the regression analysis obtained by Águas et al. (2013) for the period 19931997 only obtained significant value for the coefficient of determination for the concentration and transport ( $\mathrm{r} 2$ 0.9898); once more and the number of samples in each year did not allowed, the annual analysis to be carried out. 
During the period when the dam was built, the field data showed that the diversion of the river caused a significant reduction of transport in suspension, since the average value of the three years was $51.44 \mathrm{~kg} / \mathrm{s}$, whilst during the period from 1986 to in 1992 the average was $215.6 \mathrm{~kg} / \mathrm{s}$. On the other hand, Montanher \& Souza Filho's (2010, 2011 and 2015) data demonstrate that the transport of the suspended load remained equivalent to how it was before, as the average was greater than $200 \mathrm{~kg} / \mathrm{s}$.

\section{TRANSPORT IN SUSPENSION AFTER THE PORTO PRIMAVERA DAM}

The field data of the regression analysis obtained by ANA for the period 1999-2001 showed that it was not possible to establish a relation between the discharge and the sediment concentration ( $\mathrm{r} 2$ of 0.0312 ) or the transport in suspension ( $\mathrm{r} 2$ of 0.0910 ). The 1999 data demonstrated a reasonable ratio between flow and transport once the determination coefficient was 0.5471 . The equation Ts $=-101.8959+0.0174$.Q permitted the calculation of the average transport for that year, which was $53.24 \mathrm{~kg} / \mathrm{s}$ for an average discharge of $8916 \mathrm{~m} 3 / \mathrm{s}$ with a margin of error of $\pm 17.53 \mathrm{~kg} / \mathrm{s}$.

The analysis of Montanher \& Souza Filho's data (2010, 2011 and 2015) for the period between 1999 and 2011 also did not obtain a reliable ratio both between the discharge and between concentrations as between the former and transport ( $\mathrm{r} 2$ of 0.1389 and 0.3698 , respectively). The analysis of the annual data obtained coefficients of determination with significant values for the years 1999, 2001, 2007, 2008, 2010 and 2011. In addition, significant values were obtained for the periods 1999-2000, 2002-2005, 2004-2005, 2005-2006 and 2009-2010. The average annual transport for each year was calculated from equations with higher coefficients of determination; the results are shown in Table 13.

Table 13 - Average annual discharge (Q), equations resulting from the linear regression analysis between the discharge and transport, the coefficient of determination (r2), standard error and annual suspended transport (medium, minimum and maximum) between 1999 and 2011

(MONTANHER \& SOUZA FILHO, 2010, 2011 and 2015).

\begin{tabular}{|c|c|c|c|c|c|c|c|}
\hline \multirow{2}{*}{ Year } & \multirow{2}{*}{$\mathbf{Q}\left(\mathbf{m}^{3} / \mathbf{s}\right)$} & \multirow{2}{*}{ Equations } & \multirow{2}{*}{$\mathbf{r}^{2}$} & \multirow{2}{*}{ Standard error } & \multicolumn{3}{|c|}{ Suspended transport $(\mathrm{kg} / \mathrm{s})$} \\
\hline & & & & & Medium & Minimum & $\overline{\text { Maximum }}$ \\
\hline 1999 & 8916 & $\mathrm{Ts}=-703,6629+0,0935 . \mathrm{Q}$ & 0,7919 & 23,21 & 129,98 & 106,77 & 153,19 \\
\hline 2000 & 7903 & $\mathrm{Ts}=-425,5525+0,0606 . \mathrm{Q}$ & 0,5908 & 38,47 & 53,37 & 14,90 & 91,84 \\
\hline 2001 & 6115 & $\mathrm{Ts}=-33,334+0,0102 . \mathrm{Q}$ & 0,6105 & 17,89 & 29,04 & 11,15 & 46,93 \\
\hline 2002 & 7351 & \multirow{2}{*}{$\mathrm{Ts}=-56,3876+0,0126 . \mathrm{Q}$} & \multirow{2}{*}{0,7287} & \multirow{2}{*}{18,44} & 36,24 & 17,80 & 54,68 \\
\hline 2003 & 7779 & & & & 41,63 & 23,19 & 60,07 \\
\hline 2004 & 7417 & \multirow{2}{*}{$\mathrm{Ts}=-44,5021+0,012 . \mathrm{Q}$} & \multirow{2}{*}{0,9127} & \multirow{2}{*}{12,25} & 44,50 & 32,25 & 56,75 \\
\hline 2005 & 8320 & & & & 55,34 & 43,09 & 67,59 \\
\hline 2006 & 8650 & $\mathrm{Ts}=-54,7631+0,0121 . \mathrm{Q}$ & 0,8455 & 24,99 & 49,90 & 24,91 & 74,89 \\
\hline 2007 & 9313 & $\mathrm{Ts}=-40,7236+0,0098 . \mathrm{Q}$ & 0,7611 & 29,39 & 50,54 & 21,15 & 79,93 \\
\hline 2008 & 8141 & $\mathrm{Ts}=-250,6975+0,0354 . \mathrm{Q}$ & 0,7925 & 26,82 & 37,49 & 10,67 & 64,31 \\
\hline 2009 & 9042 & $\mathrm{Ts}=-88,6774+0,0156 . \mathrm{Q}$ & 0,7096 & 30,15 & 52,38 & 22,23 & 82,53 \\
\hline 2010 & 9935 & $\mathrm{Ts}=-101,8127+0,0162 . \mathrm{Q}$ & 0,8162 & 33,10 & 59,13 & 26,03 & 92,23 \\
\hline 2011 & 9363 & $\mathrm{Ts}=-141,9566+0,0252 . \mathrm{Q}$ & 0,6770 & 37,69 & 93,99 & 56,30 & 131,68 \\
\hline Average & 8327 & & & & 56,43 & 31,57 & 81,28 \\
\hline
\end{tabular}

The average transport in 1999, calculated from Montanher \& Souza Filho's data (2010, 2011 and 2015), was much higher than that estimated from the field data, but the coefficient of determination gives greater security to the first. The field data indicates that in 1999 the transport continued with the same order of magnitude as that calculated for the construction period (just over $50 \mathrm{~kg} / \mathrm{s}$ ). In turn, the data obtained from the images show that in 1999 transport was almost half of what had been calculated for the period and decreased further from 2000. 
The analysis of the data from Águas et al. (2013) did not achieve significant values for the period between 1999 and 2011, or for the various annual combinations that could be made. In turn, analysis of these authors' data with other image data obtained significant values in various combinations, but the coefficient of determination was always lower to those obtained from Montanher \& Souza Filho's information (2010, 2011 and 2015).

An analysis of the data obtained in the field by Crispim (2001) in 2000-2001 demonstrated that both the concentration of sediment and transport in suspension are unrelated to the river discharge, since the coefficient of determination for both linear regressions was less than 0.1 .

\section{THE BEDLOAD TRANSPORT}

The regression analysis of the data of Martins \& Stevaux (2005) and Martin et al. (2009) showed that the fluvial discharge strongly influences the bed transport, because the coefficient of determination obtained was 0.9231 . The resulting equation for the analysis is $\mathrm{Tf}=-20.7825+$ 0.0072.Q, with a standard error of $10.35 \mathrm{~kg} / \mathrm{s}$ the application of this equation allowed the calculation of the annual bed transport in the period after the dam (Table 14). The values obtained for the period between 1999 and 2002 will be re-discussed below.

Table 14 - Average annual discharge (Q) and annual bedload transport (medium, minimum and maximum) in the section of Porto São José, between 1999 and 2011 (data: MARTINS \& STEVAUX, 2005; MARTINS et al., 2009)

\begin{tabular}{c|c|c|c|c}
\multirow{2}{*}{ Year } & \multirow{2}{*}{$\mathbf{Q}\left(\mathbf{m}^{3} / \mathbf{s}\right)$} & \multicolumn{3}{|c}{ Bedload transport $(\mathbf{k g} / \mathbf{s})$} \\
\cline { 3 - 5 } & & Medium & Minimum & Maximum \\
\hline 1999 & 8916 & 43,41 & 33,06 & 53,76 \\
\hline 2000 & 7903 & 36,12 & 25,77 & 46,47 \\
\hline 2001 & 6115 & 23,25 & 12,90 & 33,60 \\
\hline 2002 & 7351 & 32,14 & 21,79 & 42,49 \\
\hline 2003 & 7779 & 35,23 & 24,88 & 45,58 \\
\hline 2004 & 7417 & 32,62 & 22,27 & 42,97 \\
\hline 2005 & 8320 & 39,12 & 28,77 & 49,47 \\
\hline 2006 & 8650 & 41,50 & 31,15 & 51,85 \\
\hline 2007 & 9313 & 46,27 & 35,92 & 56,62 \\
\hline 2008 & 8141 & 37,83 & 27,48 & 48,18 \\
\hline 2009 & 9042 & 44,32 & 33,97 & 54,67 \\
\hline 2010 & 9935 & 50,75 & 40,40 & 61,10 \\
\hline 2011 & 9363 & 46,63 & 36,28 & 56,98 \\
\hline Average & $\mathbf{8 3 2 7}$ & $\mathbf{3 9 , 1 7}$ & $\mathbf{2 8 , 8 2}$ & $\mathbf{4 9 , 5 2}$
\end{tabular}

The calculation of the bedload transport between 1993 and 1998 was based on the equation obtained by regression analysis between the product of the dune height $(\mathrm{H})$ by their displacement velocity $(\mathrm{Vd})$ and sediment transport. This analysis had the highest coefficient of determination of all the combinations ( $\mathrm{r} 2$ of 0.9851 ), with an error of $0.21 \mathrm{k} / \mathrm{s}$. The resulting equation was $\mathrm{Tf}=$ $-12.8445+21.9417$ (H.Vd).

The rate of average annual displacement of the dunes was calculated from the equation $\mathrm{Vd}=$ -29.3034+0.0108.Q (SOUZA FILHO \& RIGON, 2012) and a margin of error of $3.9 \mathrm{~m} / \mathrm{month}$ was considered. The results with the units corrected for daily values are shown in Table 15. 
Table 15 - Average annual discharge (Q) and displacement speed of subaqueous dunes (medium, minimum and maximum), in the period between 1993 and 2001

\begin{tabular}{c|c|c|c|c}
\multirow{2}{*}{ Year } & \multirow{2}{*}{$\mathbf{Q}\left(\mathbf{m}^{3} / \mathbf{s}\right)$} & \multicolumn{3}{|c}{ Displacement speed (m/day) } \\
\cline { 3 - 5 } & & Medium & Minimum & Maximum \\
\hline 1993 & 9523 & 2,45 & 2,32 & 2,58 \\
\hline 1994 & 8708 & 2,16 & 2,03 & 2,29 \\
\hline 1995 & 9175 & 2,33 & 2,20 & 2,46 \\
\hline 1996 & 8112 & 1,94 & 1,81 & 2,07 \\
\hline 1997 & 9980 & 2,62 & 2,49 & 2,75 \\
\hline 1998 & 9450 & 2,43 & 2,30 & 2,56 \\
\hline 1999 & 8916 & 2,23 & 2,10 & 2,36 \\
\hline 2000 & 7903 & 1,87 & 1,74 & 1,20 \\
\hline 2001 & 6115 & 1,23 & 1,10 & 1,36
\end{tabular}

To obtain the product between the displacement velocity of the dunes and their average height the value of $2.21 \mathrm{~m}$ was used for the period between 1993 and 1998 (STEVAUX \& TAKEDA, 2002) and the value of $2.20 \mathrm{~m}$ (CRISPIM, 2001) for the period between 1999 and 2001. The values obtained were used to estimate the bed transport; the results are in Table 16. The margin of error was not considered because it is very low.

Table 16 - Values of the product between the height of the subaqueous dunes $(\mathrm{H})$ and their displacement velocity

(Vd) and the annual bed transport (medium, minimum and maximum), in the period between 1993 and 2001

\begin{tabular}{c|c|c|c|c|c|c}
\multirow{2}{*}{ Year } & \multirow{2}{*}{ H.Vd med } & \multirow{2}{*}{ H.Vd min } & \multirow{2}{*}{ H.Vd max } & \multicolumn{3}{|c}{ Bedload transport (kg/s) } \\
\cline { 5 - 7 } & & & & Medium & Minimum & Maximum \\
\hline 1993 & 5,42 & 5,13 & 5,71 & 106,03 & 99,73 & 112,34 \\
\hline 1994 & 4,77 & 4,48 & 5,06 & 91,80 & 85,50 & 98,11 \\
\hline 1995 & 5,14 & 4,85 & 5,43 & 99,96 & 93,65 & 106,26 \\
\hline 1996 & 4,30 & 4,01 & 4,58 & 81,40 & 75,10 & 87,70 \\
\hline 1997 & 5,78 & 5,49 & 6,07 & 114,01 & 107,71 & 120,31 \\
\hline 1998 & 5,36 & 5,07 & 5,65 & 104,76 & 98,45 & 111,06 \\
\hline 1999 & 4,91 & 4,63 & 5,20 & 94,95 & 88,67 & 101,22 \\
\hline 2000 & 4,11 & 3,82 & 4,40 & 77,34 & 71,07 & 83,62 \\
\hline 2001 & 2,69 & 2,41 & 2,98 & 46,27 & 39,99 & 52,55 \\
\hline Average & & & & $\mathbf{9 0 , 7 2}$ & $\mathbf{8 4 , 4 3}$ & $\mathbf{9 7 , 0 2}$
\end{tabular}

The use of the height of the sand dunes obtained by Crispim (2001) demonstrates that it is likely that the transport in the period 1999 to 2001 was greater than shown in Table 14. The option for the results in Table 16 is because the bed forms only started to lose volume from 2002, as discussed by Martin \& Stevaux, (2005).

\section{TEMPORAL CHANGES OF DETRITAL TRANSPORT}

The results show that the transport in suspension was much higher in 1979 than in any year between 1986 and 2011. The average value in $1979(676.57 \mathrm{~kg} / \mathrm{s})$ is almost four times higher than that estimated for $1986(175.66 \mathrm{~kg} / \mathrm{s})$. This reduction is not related to the Porto Primavera dam and cannot be associated with the hydroelectric plants located upstream, as the UHE Jupiá, located just above the backwater of the Porto Primavera reservoir was completed in 1974 and the one in Rosana, located near the mouth of the Paranapanema River, was completed in 1987. 
The average transport in suspension in the period between 1986 and 1992 was $214.10( \pm 85.45)$ $\mathrm{kg} / \mathrm{s}$, increased to $222.19( \pm 60.43) \mathrm{kg} / \mathrm{s}$ in the period between 1993 and 1998, and reduced to 56.43 $( \pm 24.86) \mathrm{kg} / \mathrm{s}$ between 1999 and 2011. Despite annual variations (Figure 3), sediment transport in suspension was apparently not affected by dam construction, although annual variations were higher during this period. The same cannot be said with regard to the formation of an artificial lake, because after this, the reduction of the discharge of solids in suspension was $74.6 \%$.

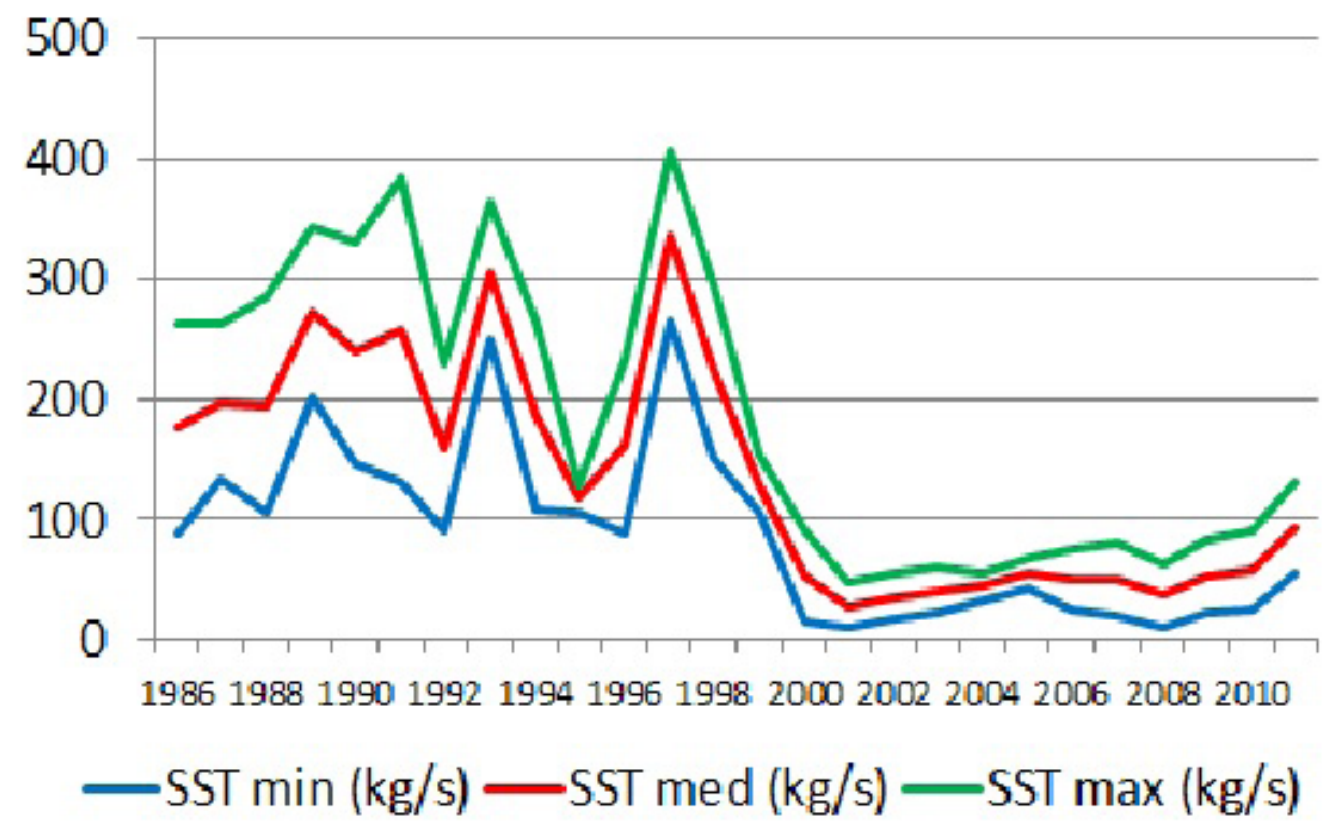

Figure 3 - The annual variation of suspended sediment transport (SST) in the Porto São José section in the period between 1986 and 2011

The bedload transport was also reduced by the formation of the reservoir. The average transport estimated for the period between 1993 and 1998 was $99.66( \pm 6.3) \mathrm{kg} / \mathrm{s}$, while the average of the period 1999-2011 was $48.08( \pm 11.42) \mathrm{kg} / \mathrm{s}$, that is, the bedload transport was reduced by $52 \%$.

However, the fluvial response to the cutting of detrital supplies promoted by UHE Porto Primavera was slow to reach the Porto São José section. In 1999 the bedload transport $(94.95 \mathrm{~kg} / \mathrm{s})$ was still equivalent to the previous period, while in the year 2000 it was slightly lower $(77.34 \mathrm{~kg}$ /s), but still within the annual variation of that period (Figure 4). If the range between 1993 and 2000 is considered, the average bedload transport was $96.28( \pm 6.3) \mathrm{kg} / \mathrm{s}$ in the period and between 2001 and 2011, it was $41.15( \pm 9.98) \mathrm{kg} / \mathrm{s}$. That is, the reduction was even higher, reaching $58.7 \%$ of what it was before the reservoir. The decrease in transport could be even greater if the subaqueous dunes have lost more height, but unfortunately, Martins et al. (2009) is the most recent data. 


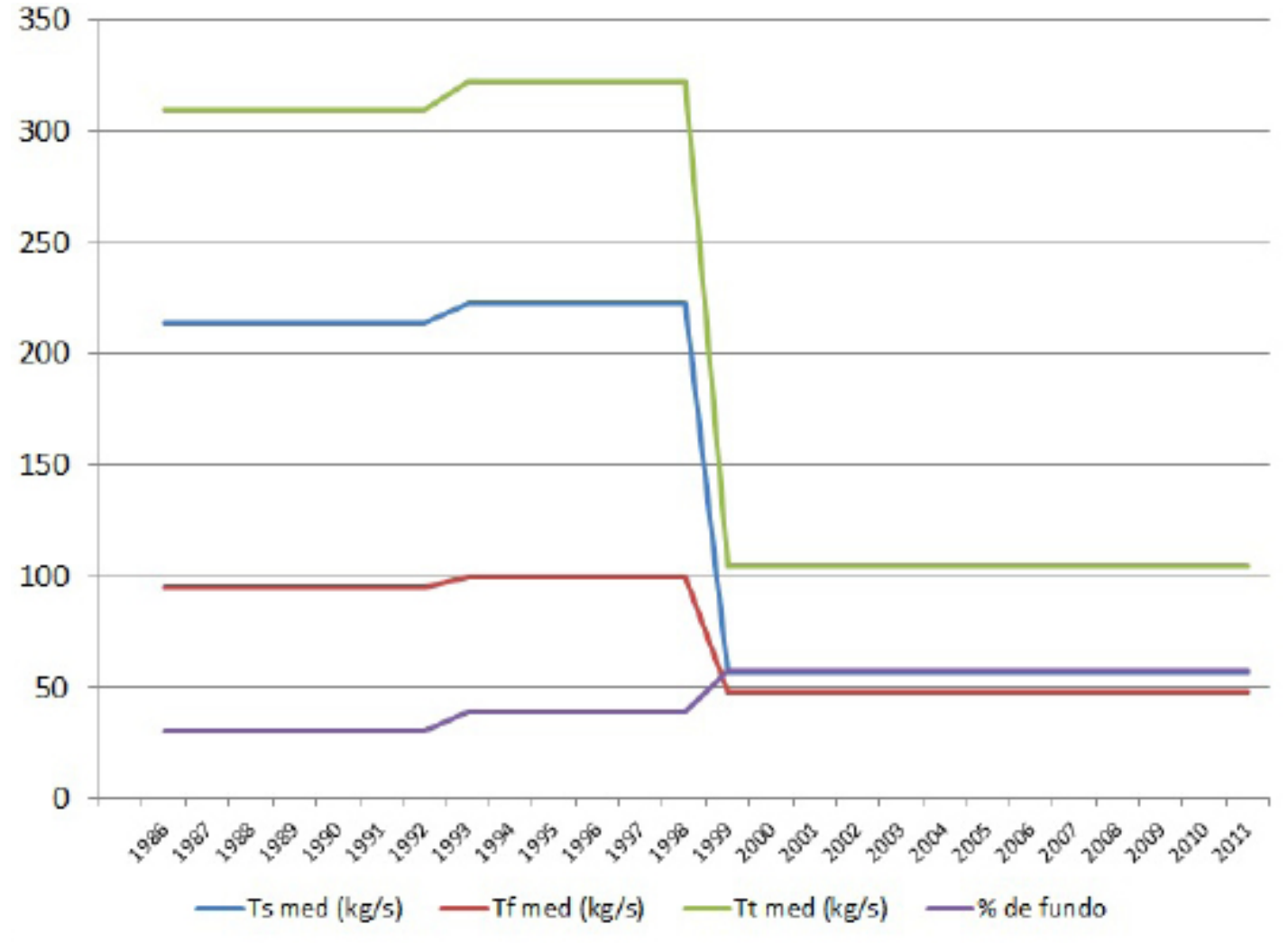

Figure 4 - Annual transportation variation of bed sediments (BLT) in the Porto São José section in the period between 1993 and 2011

Since the dam reduced transport in suspension and bed transport, the detrital transport was also reduced (Figure 5). The average solid detrital discharge between 1993 and 1998 was at least $321.85( \pm 66.73) \mathrm{kg} / \mathrm{s}, 224.93( \pm 29.49) \mathrm{kg} / \mathrm{s}$ in 1999, $130.71( \pm 45.03) \mathrm{kg} / \mathrm{s}$ in 2000, and decreased to $91.17 \mathrm{~kg} / \mathrm{s}$ between 2001 and 2011, that is, the reduction was at least $71.7 \%$.

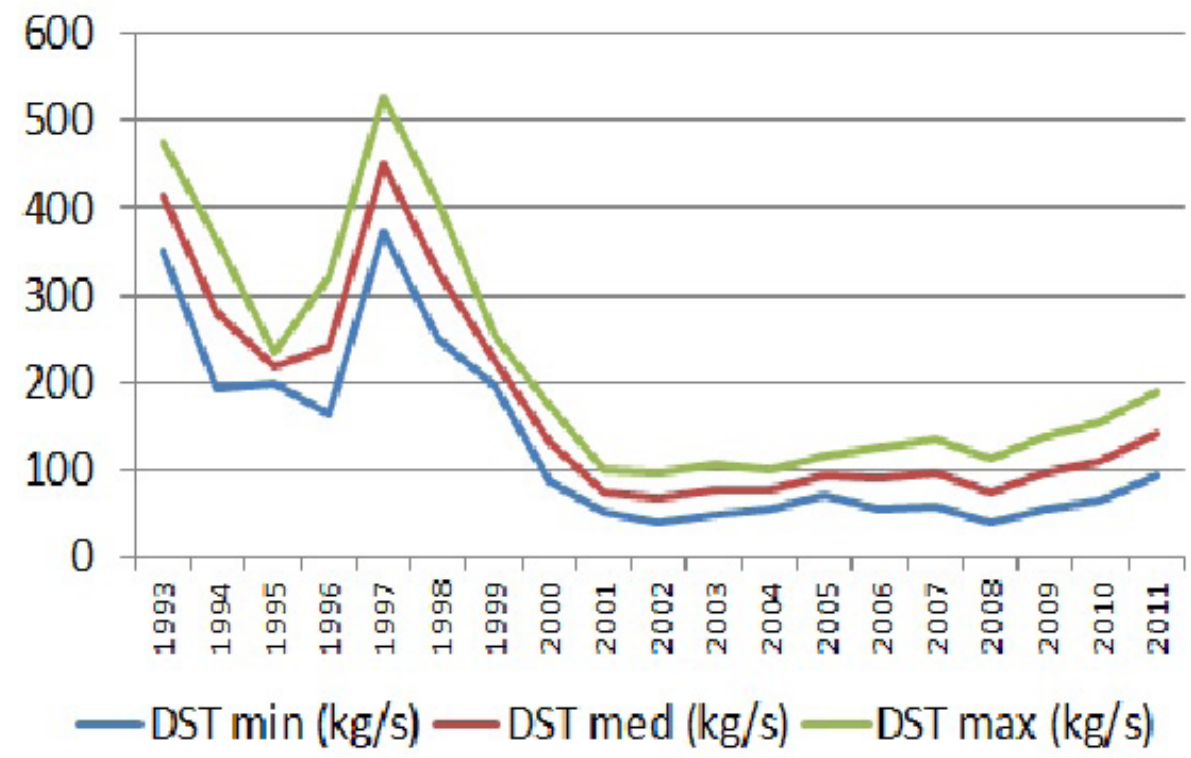

Figure 5 - Annual variation of total transport of detrital sediments (DST) in the Porto São José section in the period between 1993 and 2011.

The evaluation of two types of transport allowed the relation between the bedload and the suspended load to be established, expressed by the ratio between the bedload discharge and the 
total solid detrital discharge (Figure 6). For these reasons, since 1993, the Paraná River channel has always had more than $25 \%$ of bedload and the formation of the reservoir further increased this ratio.

\section{BLT/DST (\%)}

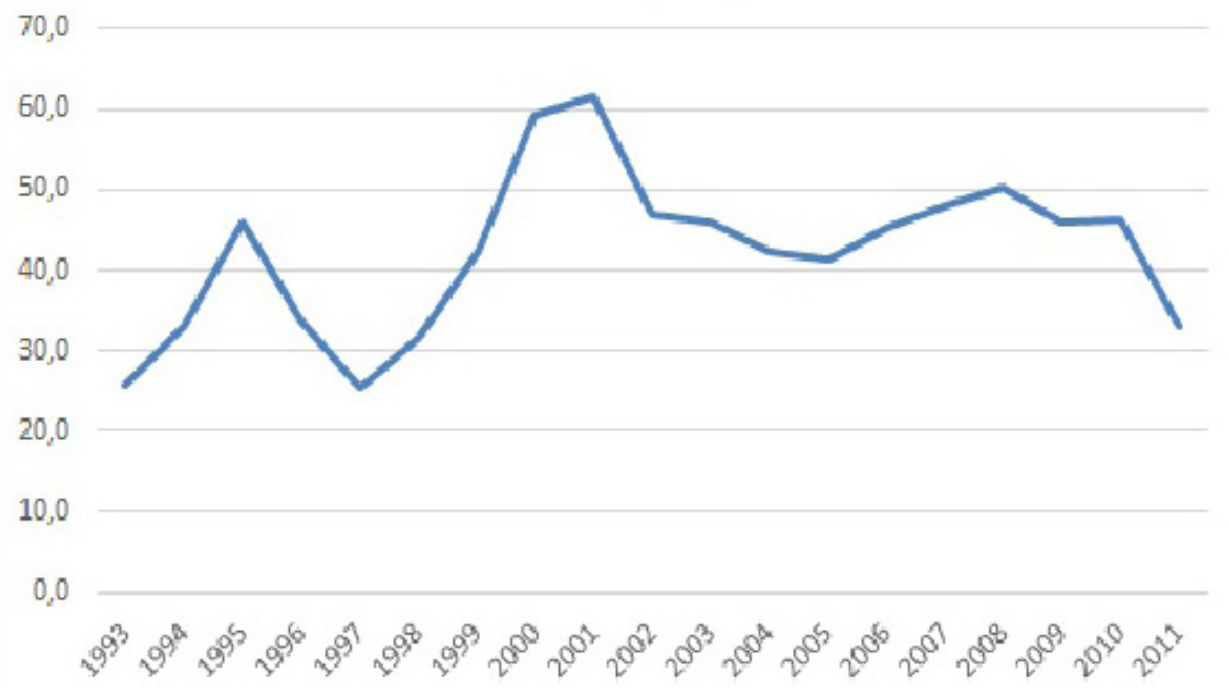

Figure 6 - Temporal variation of the ratio between the bedload and the total detrital load on the Porto São José section between 1993 and 2011

Between 1993 and 1998, the bedload represented 33.9\% of the total load and increased to $60.3 \%$ in 1999 and 2000, thanks to the almost immediate reduction in the suspended load. Since 2001, it came to represent $44.5 \%$ of the total transport of detrital sediments. That is, the channel already had a large bedload and after the dam, this proportion increased further because the reduction of the suspended load is greater than the bedload. However, it should be noted that if the reduction of bed forms have persisted, only residual forms will remain and the channel is likely to be dominated by the transport of suspended sediments.

\section{FINAL CONSIDERATIONS}

The evaluation of sediment transport in suspension made it possible to estimate the annual average transport of suspended load in 1979 and in the period between 1986 and 2011. In 1979, the average transport was $673.57( \pm 164.29) \mathrm{kg} / \mathrm{s}$, in the period between 1986 and 1992, it was $214.10( \pm$ $85.45) \mathrm{kg} / \mathrm{s}$, in the period between 1993 and 1998 it was $222.19( \pm 60.43) \mathrm{kg} / \mathrm{s}$ and $56.43( \pm 24.86)$ $\mathrm{kg} / \mathrm{s}$ between the years 1999 and 2011. The construction of the dam did not affect the transport in suspension but its completion reduced the suspended load by $74.6 \%$.

The data available enabled an estimate of the bed transport in the period between the years 1993 and 2011. In the construction period, the transport was $99.66( \pm 6.3) \mathrm{kg} / \mathrm{s}$, in 1999, in 2000, it was $86.15( \pm 6.3) \mathrm{kg} / \mathrm{s}$ and $41.15( \pm 9.98) \mathrm{kg} / \mathrm{s}$ between 2001 and 2011, and that is to say, the completion of the dam reduced the bed transport by $58.7 \%$.

The total transport of detrital sediments during the construction of the dam was $321.85( \pm$ $66.73) \mathrm{kg} / \mathrm{s}$ and was reduced to $177.82( \pm 37.11) \mathrm{kg} / \mathrm{s}$ in 1999 and 2000, and $91.17( \pm 37.11) \mathrm{kg} / \mathrm{s}$ from 2001. Therefore, the formation of the reservoir decreased the total transport by $57.5 \%$. 
The dam also affected the ratio between the suspended load and the bedload because the first had a greater reduction than the second did. Thus, the bed transport represented $33.9 \%$ of the total load in the construction period, rose to $60.3 \%$ between 1999 and 2000 , and decreased to $44.5 \%$ from 2001.

\section{ACKNOWLEDGMENTS}

This article was supported by the projects: "The Paraná River floodplain: Structure and Environmental Process" (PELD) and "Environmental Diagnosis of the Paraná River Plain: The Transformations of the Fluvial Channel" (307676 / 2009-9 CNPq process).

\section{BIBLIOGRAPHIC REFERENCE}

ÁGUAS, T.A.; SOUZA FILHO, E.E.; GONCALVES JUNIOR, F.A. Estimativa da concentração de sedimentos suspensos do rio Paraná, em Porto São José, a partir de imagens LANDSAT5/TM. In: Simpósio Brasileiro de Geografia Física Aplicada, XV. 2013, Vitória-ES. Anais....Vitória: Departamento de Geografia UFES, 2013. p, 538-545. Disponível em http:/www.xvsbgfa2013.com.br/anais/trabalhos/Eixo03.pdf\#page=538. Acesso em 12 de dezembro de 2013.

CHIEN, N. 1985 Changes in river regime after the construction of upstream reservoirs. Earth Surface Processes and Landforms, v. 10, 143-159. 1985.

CRISPIM, Jefferson. Queiroz. Alterações na hidrologia do canal após construção de reservatório a montante: o caso da Usina Hidrelétrica de Porto Primavera, Rio Paraná. 2001. 25 f. Dissertação (Mestrado) - Universidade Estadual de Maringá, Pós-Graduação em Ecologia de Ambientes Aquáticos Continentais, Maringá, PR. 2001.

GRIMSHAW, D.L. \& LEWIN, J. Reservoir effects on sediment yield. Journal of Hydrology, v. 47, 163-171. 1980.

ITAIPU BINACIONAL. Estudo sobre a carga suspensa na bacia do rio Paraná no período de 19861988. Relatório interno s/n. s/vol. Foz do Iguaçu, 1990.

ITAIPU BINACIONAL. Efeitos sedimentológicos no reservatório da UHE Itaipu. Relatório referente à reunião do Board de Consultores Civis, 37 pp. Foz do Iguaçu, 1996.

MARTINS, D.P. \& STEVAUX, J.C. Formas de leito e transporte de carga de fundo do Alto Rio Paraná. Revista Brasileira de Geomorfologia, v. 6, p. 43-50, 2006.

MARTINS, D. P.; BRAVARD, J.P. \& STEVAUX, J.C. Dynamics of water flow and sediments in the Upper Paraná River between Porto Primavera and Itaipu dams, Brazil. Latin American Journal of Sedimentology and Basin Analysis, v. 16, n ${ }^{\circ}$ 2, 111-118. 2009.

MONTANHER, O.C. \& SOUZA FILHO, E.E. Avaliação da Alteração da concentração de sedimentos em suspensão em eventos de cheia do Rio Paraná: O uso de imagens orbitais para avaliação de impactos provocados pela barragem de Porto Primavera Revista de Geografia (Recife), v. espec., p. 164-176. 2010. MONTANHER, O.C.; SOUZA FILHO, E.E. Geração de algoritmos para predição de carga em suspensão em corpos hídricos da bacia hidrográfica do Rio Paraná com uso de imagens Landsat TM5. In: Simpósio Brasileiro de Sensoriamento Remoto, XV, 2011, Curitiba. Anais... São José dos Campos: INPE, 2011. v. 1, p. 5340-5347.

PETTS, G.E. Complex Response of River Channel Morphology Subsequent to Reservoir Construction. Progress in Physical Geography, v 3, 329-362. 1979.

PETTS, G.E. Impounded rivers: perspectives for ecological management. Chichester: John Wiley. 326 pp. 1984.

PETTS, G.E., GURNELL, A.M. Dams and geomorphology: Research progress and future directions. Geomorphology, v. 71, 27-47. 2005.

RAUBER, T.; LUCHESE, E.B.; LENZI, E.; OLIVEIRA, M.A. \& PALÁCIO, S.M. Nível de concentração 
dos macronutrientes N, P e K, que aportam nos rios Paraná e Baía, na região de Porto Rico - PR. Acta Limnologica Brasiliensia, vol. IV, 239-245. 1992.

ROCHA, J.A. \& SOUZA FILHO, E.E. Características gemorfológicas do canal do Rio Paraná à jusante da barragem de Porto Primavera: variação temporal e espacial dos sedimentos suspensos, de fundo e de algumas variáveis limnológicas. In: Dalva Helena de Medeiros. (Org.). Relação Homem/Natureza sob a Ótica da Interdisciplinaridade. Campo Mourão: Editora Fecilcam, v. 1, p. 225-249. 2008.

SOUZA FILHO, E.E. Diagnóstico do meio físico e condições emergentes da planície do rio Paraná em Porto Rico. Geonotas (UEM), Maringá, v. 03, n. 03, p. 1-10, 1999.

SOUZA FILHO, E.E. \& RIGON, B.T.C. Avaliação da velocidade de deslocamento de barras fluviais do rio Paraná por meio de imagens CBERS/CCD. Revista Brasileira de Geomorfologia, v. 13, p. 57-64, 2012.

SOUZA FILHO, E.E.; ZANETTI, K.; PINESE, J.P.P. \& FRANÇA, V. A hidroquímica do Rio Paraná após a barragem de Porto Primavera. Boletim de Geografia, v. 28, p. 101-112, 2010.

Submitted 23 june 2016

Accepted 31 august 2016 